\title{
Effect of Nutrient Management Approaches and Major Nutrients on Dry Direct Seeded Rice (dry- DSR) in TBP Command Area
}

\author{
V. Rajesh", S.R. Balanagoudar, H. Veeresh, Ashok Kumar Gaddi and Y.M. Ramesh \\ Department of Soil Science and Agricultural Chemistry, College of Agriculture, \\ Raichur, Karnataka, India \\ *Corresponding author
}

\begin{abstract}
A B S T R A C T
Keywords

Target yield, SSNM, STCR, STL, Dry-DSR

Article Info

Accepted:

10 January 2018

Available Online:

10 February 2018

The present experiment was conducted during kharif-2016 at ARS, Dhadesugur with ten treatments and three replications. Results revealed that the significant higher grain and straw yield were recorded with nutrients applied through SSNM approach (7,358 and 10,674 $\mathrm{kg} \mathrm{ha}^{-1}$, respectively) as compare to other treatments. Further, omission of major nutrients has resulted in yield loss of 56 per cent $(-\mathrm{N}), 16.5$ per cent $(-\mathrm{P})$ and 20 per cent (-K) compared to SSNM treatment. Application of fertilizers as per SSNM approach noticed higher nitrogen and phosphorus use efficiency (94.05 and $49.98 \%$, respectively) and potassium use efficiency of $(220.91 \%)$ was noticed in STL rating method.
\end{abstract}

\section{Introduction}

Rice is a vital food to more than half of the world's population. Rice accounts for 55 per cent of total cereal production in the country. The per capita food intake in India is 2,234 calories per day of which 30 per cent comes from rice. In India, rice is grown in an area of $43.95 \mathrm{~m}$ ha with an annual production of about $106.54 \mathrm{mt}$ and the productivity is about $2.37 \mathrm{t}$ $\mathrm{ha}^{-1}$ (Anon., 2015). In Karnataka, rice is cultivated in command areas of Cauvery, Tungabhadra and Upper Krishna, where conventional puddling and transplanting are the major system of cultivation. The total area under rice in Karnataka is $1.42 \mathrm{~m}$ ha with an annual production of $3.5 \mathrm{mt}$ and the productivity to the tune of $2.63 \mathrm{t} \mathrm{ha}^{-1}$ (Anon., 2015).

The nutrient requirement of direct-seeded rice is probably lower than that of transplanted rice during early growth stages. In TBP areas are known for using imbalance dose of nutrients with higher tendency for $\mathrm{N}$ application. This also causes environmental damage and increase the total cost of production as heavy $\mathrm{N}$ use makes the rice crop more susceptible to pest and disease and thus increases cost of protection. Unbalanced fertilizer use also causes soil degradation and particularly when $\mathrm{N}$ fertilizer use drives the removal of $\mathrm{P}$ and $\mathrm{K}$ 
that are not replenished by the addition of fertilizer nutrients. So it has been considered worthwhile to study the uptake and availability of nutrients in dry- DSR as influenced by omission of major nutrients.

\section{Materials and Methods}

The experiment was carried out on clayey soil during kharif-2016 at ARS Dhadesugur to study the nutrient uptake, use efficiency and yield of DSR as influenced by different nutrient approaches. Initially the soil of experimental plot had $\mathrm{pH}$ of 8.23 , EC of 0.51 $\mathrm{dS} \mathrm{m} \mathrm{m}^{-1}$, organic carbon of $4.6 \mathrm{~g} \mathrm{~kg}^{-1}$ and available nitrogen, phosphorus and potassium were 167,55 and $300 \mathrm{~kg} \mathrm{ha}^{-1}$, respectively.

The experiment was laid out in randomized block design with the ten treatments and three replications viz., $\mathrm{T}_{1^{-}}$Absolute Control, $\mathrm{T}_{2^{-}}$ SSNM approach targeted yield of $70 \mathrm{q} \mathrm{ha}^{-1}$, $\mathrm{T}_{3^{-}}$Recommended Dose of Fertilizer (Urea, DAP and MoP), $\mathrm{T}_{4}$ - Recommended Dose of Fertilizer (Urea: SSP: MoP), $\mathrm{T}_{5^{-}}$Soil Test Ratings method (STL) (Urea: SSP: MoP), $\mathrm{T}_{6^{-}}$ $\mathrm{N}$ Omission with Recommended Dose of $\mathrm{P}$ and $\mathrm{K}$ as per STL method, $\mathrm{T}_{7^{-}} \mathrm{P}$ Omission with Recommended Dose of $\mathrm{N}$ and $\mathrm{K}$ as per STL method, $\mathrm{T}_{8^{-}} \mathrm{K}$ Omission with Recommended Dose of $\mathrm{N}$ and $\mathrm{P}$ as per STL method, $\mathrm{T}_{9-}$ STCR method and $\mathrm{T}_{10}$-Farmer Practice. The soil samples were analyzed by adopting standard procedures (Nitrogen Subbaiah and Assija method (1956), Phosphorus and Potassium - Jackson (1973)).

\section{Results and Discussion}

\section{Grain yield and yield attributes of paddy}

The present study showed that, the effect of nutrient application through targeted yield approach exerted significant influence on the grain and straw yield of dry DSR. The grain yield of dry DSR recorded was higher in treatment receiving $\mathrm{T}_{2}$ : $\mathrm{SSNM}$ approach $\left(7,358 \mathrm{~kg} \mathrm{ha}^{-1}\right)$ and it was found on par with $\mathrm{T}_{9}$ : STCR approach $\left(7,050 \mathrm{~kg} \mathrm{ha}^{-1}\right)$ and followed by $\mathrm{T}_{5}$ : STL $\left(6,783 \mathrm{~kg} \mathrm{ha}^{-1}\right)$ and significantly lowest grain yield was recorded in absolute control $\left(1,883 \mathrm{~kg} \mathrm{ha}^{-1}\right)$ (Table 1). The significantly higher straw yield was recorded in $\mathrm{T}_{2}$ : SSNM $\left(10,674 \mathrm{~kg} \mathrm{ha}^{-1}\right)$ followed by $\mathrm{T}_{9}$ : STCR approach $(10,229 \mathrm{~kg}$ $\mathrm{ha}^{-1}$ ) and the lowest was recorded in $\mathrm{T}_{1}$ : Absolute control $\left(2,782 \mathrm{~kg} \mathrm{ha}^{-1}\right)$. The higher grain yield can be attributed to the ability of targeted yield approaches to satisfy the nutrient demand of crop more efficiently. The higher grain yield of dry DSR was also due to better translocation of photosynthates from source to sink and higher yield attributing characters viz., panicle length, number of grains per panicle, filled grains per panicle, lower number unfilled grains per panicle, and higher test weight. The results are in confirmation with the findings of Dhillon et al., (2006) who reported higher grain yield (46.0 $\mathrm{q} \mathrm{ha}^{-1}$ ) with the application of fertilizer based on targeted yield (45.0 q ha ${ }^{-1}$ ) approach when compared to farmer's practice, RDF and soil test based applications.

These results are also coroborated with the findings of Doberman et al., (2000), Biradar et al., (2006), Keram et al., (2012), Umesh et al., (2014) and Singh et al., (2014). Grain yield is governed by the factors which have direct or indirect impact. The factors which have direct influence on the grain yield are the yield components viz., panicle length, number of grains panicle ${ }^{-1}$ (Table 1), filled grains panicle $^{-1}$, unfilled grains panicle ${ }^{-1}$, grain filling per cent (Table 1) and test weight have an indirect influence on grain yield through the yield components, however all these growth components could have been promoted by more quantity of nutrients made available by the treatments to dry DSR and evidenced through higher uptake of nutrients viz., nitrogen, phosphorous and potassium. 
The highest number of grains per panicle was recorded in treatment with application of nutrients through SSNM approach (296) followed by STCR approach (278) and STL method (256) over absolute control (144) (Table 1). Significant difference in the number of grains per panicle of dry DSR obtained by higher amounts of nutrients supplied through targeted yield approaches as evidenced by their nutrient content and higher number of grains per panicle. Lesser number of grains per panicle was recorded in absolute control (144) and $\mathrm{K}$ omitted treatment (161) which might be due to the inadequate supply of plant nutrients this might be due to adequate supply of potassium fertilizer during early and panicle initiation stage which helped in proper filling of grains which resulted in higher number of plump grains and thus increased the number of grains panicle ${ }^{-1}$ and reduced grain filling percentage. The improved grain filling with potassium application was due to increased photosynthetic activity which stimulated some vital biochemical processes. The present findings are in agreement with findings of Venkateshwarlu and Singh (1980). However, significantly higher 1000 seed weight of dry DSR grain (17.80 g) was recorded with SSNM approach over absolute control (12.98 g) and STCR approach (16.54 g) and it was found on par with STL method (16.29 g) and (Table 1). Higher 1000 seed weight of dry DSR was mainly attributed to higher dry matter production in plants (Table 1) which might have supplied required photosynthates to the reproductive parts more precisely to the seed. Thus, due to availability of photosynthates the seed might have developed fully and resulted in plump grains and hence recorded higher test weight. These results are in accordance with the findings of Ravi and Rao (1992) who had reported that maximum test weight, number of filled grains per panicle and yield were obtained due to application of higher potassium in two equal splits as basal and at panicle initiation stage.

\section{Grain yield}

The present study showed that, the effect of nutrient application through targeted yield approach exerted significant influence on the grain and straw yield of dry DSR (Table 1). The grain yield of dry DSR recorded was higher in treatment receiving $\mathrm{T}_{2}$ : SSNM approach $\left(7,358 \mathrm{~kg} \mathrm{ha}^{-1}\right)$ and it was found on par with $\mathrm{T}_{9}$ : STCR approach $\left(7,050 \mathrm{~kg} \mathrm{ha}^{-1}\right)$ and followed by $\mathrm{T}_{5}$ : STL $\left(6,783 \mathrm{~kg} \mathrm{ha}^{-1}\right)$ and significantly lowest grain yield was recorded in absolute control $\left(1,883 \mathrm{~kg} \mathrm{ha}^{-1}\right)$ (Table 1). The significantly higher straw yield was recorded in $\mathrm{T}_{2}$ : SSNM $\left(10,674 \mathrm{~kg} \mathrm{ha}^{-1}\right)$ followed by $\mathrm{T}_{9}$ : STCR approach $(10,229 \mathrm{~kg}$ $\mathrm{ha}^{-1}$ ) and the lowest was recorded in $\mathrm{T}_{1}$ : Absolute control $\left(2,782 \mathrm{~kg} \mathrm{ha}^{-1}\right)$. The higher grain yield can be attributed to the ability of targeted yield approaches to satisfy the nutrient demand of crop more efficiently. The higher grain yield of dry DSR was also due to better translocation of photosynthates from source to sink and higher yield attributing characters viz., panicle length, number of grains per panicle, filled grains per panicle, lower number unfilled grains per panicle, and higher test weight. The results are in confirmation with the findings of Dhillon et al., (2006) who reported higher grain yield (46.0 $\mathrm{q} \mathrm{ha}^{-1}$ ) with the application of fertilizer based on targeted yield (45.0 q ha ${ }^{-1}$ ) approach when compared to farmer's practice, RDF and soil test based applications. These results are also coroborated with the findings of Singh et al., (2014).

Further, omission of major nutrients has resulted in yield loss of 52 per cent $(-\mathrm{N}), 6.5$ per cent (-P) and 10 per cent (-K) respectively, compared to farmer's practice. These results are in conformity with the findings of Wang et al., (2007) and Shaobing et al., (2006) they reported that on average SSNM reduced $\mathrm{N}$ fertilizer by $32 \%$ and increased grain yield by $5 \%$ compared with farmer's $\mathrm{N}$ practices in 
China and other major rice-growing countries of South East Asia.

\section{Nutrient uptake}

The effect of different nutrient management approaches on nitrogen, phosphorus, and potassium uptake by dry direct seeded rice after harvest presented in the Table 2 the results were found to be significant.

The targeted approach of SSNM significantly increased the uptake of nitrogen, phosphorus and potassium by grain and straw in dry DSR over other approaches. Significantly the highest nitrogen (105.44 $\mathrm{kg} \mathrm{ha}^{-1}$ ), phosphorus $\left(28.86 \mathrm{~kg} \mathrm{ha}^{-1}\right)$ and potassium $\left(24.62 \mathrm{~kg} \mathrm{ha}^{-1}\right)$ content in grain as well as highest $\mathrm{N}(129.45$ $\left.\mathrm{kg} \mathrm{ha}^{-1}\right), \mathrm{P}\left(8.85 \mathrm{~kg} \mathrm{ha}^{-1}\right)$ and $\mathrm{K}(118.80 \mathrm{~kg}$ $\mathrm{ha}^{-1}$ ) content in straw were recorded in SSNM and followed by STCR targeted approach and STL (Table 1). It might be due to application of balanced fertilization based on target yield resulting in higher total NPK \& S uptake.

The higher nutrient uptake is well reflected in terms of higher grain and straw yield of dry DSR (Table 2). Obviously this could be due to application of nitrogen in four splits, potash in two splits and along with required phosphatic fertilizers; this might be the reason for higher uptake of nutrients by the rice crop. The results are in line with the different research workers viz., Sharma and Mittra (1989) reported that uptake of $\mathrm{N}, \mathrm{P}$ and $\mathrm{K}$ increased significantly with increasing $\mathrm{N}$ levels. Further, Mukopadhaya and Majumdar (2010) conducted field experiments for evaluating the impact of soil test-based fertilization on rainfed rice.

Table.1 Grain yield and yield parameters as influenced major nutrients in dry-DSR at harvest

\begin{tabular}{|c|c|c|c|c|c|c|c|c|}
\hline \multirow[t]{2}{*}{ Treatments } & \multirow{2}{*}{$\begin{array}{c}\text { Panicle } \\
\text { Length } \\
\text { (cm) }\end{array}$} & \multicolumn{3}{|c|}{ No. of grains panicle ${ }^{-1}$} & \multirow{2}{*}{$\begin{array}{c}\text { Grain filling } \\
\%\end{array}$} & \multirow{2}{*}{$\begin{array}{c}\text { Test } \\
\text { Weight } \\
\text { (g) }\end{array}$} & \multirow{2}{*}{$\begin{array}{c}\text { Grain } \\
\text { Yield } \\
\left(\mathrm{kg} \mathrm{ha}^{-1}\right)\end{array}$} & \multirow{2}{*}{$\begin{array}{c}\text { Straw Yield } \\
\left(\mathrm{kg} \mathrm{ha}^{-1}\right)\end{array}$} \\
\hline & & Filled & $\begin{array}{l}\text { Unfill } \\
\text { ed }\end{array}$ & Total & & & & \\
\hline $\mathbf{T}_{1}$ & 21.37 & 93 & 51 & 144 & 64.51 & 12.98 & 1883 & 2782 \\
\hline $\mathbf{T}_{2}$ & 24.16 & 280 & 16 & 296 & 94.59 & 17.80 & 7358 & 10674 \\
\hline $\mathbf{T}_{3}$ & 22.02 & 229 & 25 & 254 & 90.30 & 16.02 & 6603 & 9579 \\
\hline $\mathbf{T}_{4}$ & 23.17 & 226 & 25 & 251 & 89.92 & 15.12 & 6533 & 9486 \\
\hline $\mathbf{T}_{5}$ & 23.78 & 235 & 21 & 256 & 91.73 & 16.29 & 6783 & 9842 \\
\hline $\mathrm{T}_{6}$ & 23.36 & 160 & 24 & 184 & 86.95 & 13.91 & 3200 & 4634 \\
\hline $\mathbf{T}_{7}$ & 23.26 & 183 & 21 & 204 & 89.70 & 15.11 & 6173 & 8968 \\
\hline $\mathbf{T}_{8}$ & 24.16 & 115 & 47 & 161 & 71.05 & 15.58 & 5967 & 8673 \\
\hline $\mathbf{T}_{9}$ & 23.99 & 258 & 20 & 278 & 92.69 & 16.54 & 7050 & 10229 \\
\hline $\mathbf{T}_{10}$ & 23.29 & 205 & 40 & 245 & 83.63 & 16.07 & 6500 & 9428 \\
\hline S. Em. \pm & 0.50 & 3.68 & 1.30 & 3.33 & 0.68 & 0.37 & 158 & 254 \\
\hline CD@5\% & 1.49 & 10.74 & 3.80 & 9.72 & 1.98 & 1.09 & 460 & 742 \\
\hline
\end{tabular}


Table.2 Uptake of nutrients as influenced by major nutrients in dry-DSR after harvest

\begin{tabular}{|c|c|c|c|c|c|c|c|c|c|}
\hline \multirow[t]{3}{*}{ Treatment } & \multicolumn{3}{|c|}{ Nitrogen } & \multicolumn{3}{|c|}{ Phosphorus } & \multicolumn{3}{|c|}{ Potassium } \\
\hline & \multicolumn{9}{|c|}{$\left(\mathrm{kg} \mathrm{ha}^{-1}\right)$} \\
\hline & Grain & Straw & Total & Grain & Straw & Total & Grain & Straw & Total \\
\hline$T_{1}$ & 16.81 & 12.65 & 41.47 & 6.99 & 2.75 & 9.74 & 5.78 & 23.18 & 28.95 \\
\hline $\mathbf{T}_{2}$ & 105.44 & 129.45 & 220.17 & 28.86 & 8.85 & 37.22 & 24.62 & 118.80 & 139.41 \\
\hline$T_{3}$ & 70.61 & 68.96 & 132.31 & 21.85 & 7.47 & 29.32 & 21.59 & 95.53 & 117.13 \\
\hline$T_{4}$ & 72.29 & 75.19 & 142.73 & 22.67 & 8.48 & 31.16 & 21.93 & 99.72 & 126.09 \\
\hline$T_{5}$ & 84.56 & 92.55 & 173.74 & 26.15 & 8.02 & 34.18 & 20.61 & 91.38 & 116.00 \\
\hline $\mathrm{T}_{6}$ & 31.20 & 32.08 & 77.80 & 12.03 & 4.79 & 16.82 & 10.20 & 49.05 & 59.25 \\
\hline$T_{7}$ & 62.22 & 81.37 & 139.70 & 18.27 & 6.33 & 24.60 & 19.55 & 96.32 & 115.87 \\
\hline$T_{8}$ & 72.68 & 93.44 & 158.83 & 20.83 & 7.57 & 28.40 & 13.63 & 81.23 & 94.86 \\
\hline$T_{9}$ & 95.91 & 105.80 & 205.01 & 26.63 & 8.52 & 35.15 & 23.90 & 104.15 & 123.62 \\
\hline$T_{10}$ & 75.27 & 92.24 & 136.86 & 22.65 & 8.37 & 31.51 & 22.09 & 92.78 & 114.87 \\
\hline S. Em. \pm & 3.94 & 7.81 & 7.94 & 1.48 & 0.87 & 1.92 & 1.07 & 6.75 & 7.14 \\
\hline CD@5\% & 11.49 & 22.81 & 23.17 & 4.31 & 2.54 & 5.62 & 3.11 & 19.71 & 20.83 \\
\hline
\end{tabular}

Table.3 Nutrient use efficiency as influenced by major nutrients in dry-DSR after harvest

\begin{tabular}{|c|c|c|c|}
\hline & \multicolumn{4}{|c|}{ Nutrient use efficiency \% } & \\
\hline Treatments & Nitrogen & Phosphorus & Potassium \\
\hline $\mathrm{T}_{1}$ & 0.00 & 0.00 & 0.00 \\
\hline $\mathrm{T}_{2}$ & 94.05 & 49.98 & 59.21 \\
\hline $\mathrm{T}_{3}$ & 60.56 & 26.11 & 117.56 \\
\hline $\mathrm{T}_{4}$ & 67.51 & 28.56 & 129.51 \\
\hline $\mathrm{T}_{5}$ & 75.58 & 39.11 & 220.91 \\
\hline $\mathrm{T}_{6}$ & 0.00 & 11.33 & 60.59 \\
\hline $\mathrm{T}_{7}$ & 79.86 & 0.00 & 173.83 \\
\hline $\mathrm{T}_{8}$ & 67.06 & 29.86 & 0.00 \\
\hline $\mathrm{T}_{9}$ & 84.74 & 24.67 & 78.89 \\
\hline $\mathrm{T}_{10}$ & 39.58 & 13.44 & 67.12 \\
\hline Mean & 56.89 & 22.30 & 90.76 \\
\hline
\end{tabular}

Table.4 Soil physico-chemical properties as influenced by various treatments after the harvest of dry-DSR

\begin{tabular}{|c|c|c|c|}
\hline Treatments & Avail. $\mathbf{N}\left(\mathrm{kg} \mathrm{ha}^{-1}\right)$ & Avail. $\mathbf{P}_{2} \mathbf{O}_{\mathbf{5}}\left(\mathrm{kg} \mathrm{ha}^{-1}\right)$ & Avail. $\mathbf{K}_{2} \mathbf{O}\left(\mathbf{k g ~ h a}^{-1}\right)$ \\
\hline $\mathrm{T}_{1}$ & 115.20 & 34.27 & 191.03 \\
\hline $\mathrm{T}_{2}$ & 133.59 & 47.48 & 253.12 \\
\hline $\mathrm{T}_{3}$ & 128.58 & 47.23 & 239.23 \\
\hline $\mathrm{T}_{4}$ & 133.59 & 46.20 & 221.54 \\
\hline $\mathrm{T}_{5}$ & 104.74 & 47.48 & 248.08 \\
\hline $\mathrm{T}_{6}$ & 86.76 & 37.22 & 210.26 \\
\hline $\mathrm{T}_{7}$ & 129.62 & 37.54 & 247.89 \\
\hline $\mathrm{T}_{8}$ & 128.99 & 38.89 & 225.19 \\
\hline $\mathrm{T}_{9}$ & 132.55 & 65.45 & 247.59 \\
\hline $\mathrm{T}_{10}$ & 165.58 & 44.28 & 263.31 \\
\hline S. $\mathbf{E m}_{\mathbf{m}} \pm$ & 1.55 & 0.58 & 3.58 \\
\hline CD @ $\%$ & 0.27 & 0.45 & 0.20 \\
\hline
\end{tabular}


Table.5 Cost of cultivation, Net returns, B: C ratio as influenced major nutrients in dry-DSR

\begin{tabular}{|c|c|c|c|c|}
\hline Treatment & $\begin{array}{c}\text { Cost of cultivation } \\
\left(₹ \mathrm{ha}^{-1}\right)\end{array}$ & $\begin{array}{c}\text { Gross returns } \\
\left(\text { ₹ ha }^{-1}\right)\end{array}$ & $\begin{array}{c}\text { Net returns } \\
\left(₹ \mathbf{h a}^{-1}\right)\end{array}$ & B:C ratio \\
\hline T1 & 27400 & 40620 & 13220 & 1.5 \\
\hline T2 & 42867 & 158431 & 115564 & 3.7 \\
\hline T3 & 42152 & 142176 & 100024 & 3.4 \\
\hline T4 & 43234 & 140681 & 97447 & 3.3 \\
\hline T5 & 42629 & 146054 & 103425 & 3.4 \\
\hline T6 & 40197 & 68887 & 28690 & 1.7 \\
\hline T7 & 38328 & 132935 & 94607 & 3.5 \\
\hline T8 & 41633 & 128492 & 86859 & 3.1 \\
\hline T9 & 45025 & 151795 & 106770 & 3.4 \\
\hline T10 & 48714 & 139949 & 91235 & 2.9 \\
\hline S. Em. & - & - & 3418 & 0.1 \\
\hline CD@5\% & - & - & 9977 & 0.2 \\
\hline
\end{tabular}

\section{Nutrient use efficiency}

The data pertaining to nutrient use efficiency of nitrogen, phosphorus and potassium after harvest of dry direct seeded rice as influenced by different nutrient management approaches were presented in Table 3.

Nutrient use efficiency is the ratio of difference between the nutrient uptake by a crop in fertilized plot and nutrient uptake by a crop in control plot to the amount of nutrient applied. Hence, the nutrient use efficiency depends on nutrient uptake by crop in control and fertilized plot and the amount of nutrient supplied to the respective plots. The higher nitrogen use efficiency (94.05\%) was recorded in SSNM approach followed by the application of fertilizers through STCR approach $(84.74 \%)$. Whereas, lowest nitrogen use efficiency $(39.58 \%)$ was observed in farmer practice. The higher use efficiency of phosphorus (49.98\%) was observed with SSNM approach followed by treatment receiving soil test rating method $(39.11 \%)$. Lowest phosphorus use efficiency $(11.33 \%)$ was observed in $\mathrm{N}$ omitted treatment. The higher potassium use efficiency of $(220.91 \%)$ was obtained with soil test rating method followed by the $\mathrm{P}$ omitted treatment $(173.83 \%)$ as compared to rest of other treatments and lowest potassium use efficiency $(59.21 \%)$ was noticed (Table 3 ). The results are in conformity with the findings of Ferguson et al., (2002) reported that recovery efficiency of fertilizer N (REN) in rice increased significantly with SSNM. On an average REN increased by about 29 per cent high with SSNM compared to farmer's fertilizer practice. Abdulrahaman et al., (2002) reported that application of nutrients through SSNM approach increased fertilizer use efficiency of $\mathrm{N}$ by (12 to $36 \%$ ), $\mathrm{P}$ (8 to $13 \%)$ and $\mathrm{K}(>100 \%)$ and average rice yield in the SSNM (5.6 to $6.4 \mathrm{t} \mathrm{ha}^{-1}$ ) over farmer's practice. SSNM supported to increase the nutrient use efficiency of $\mathrm{N}, \mathrm{P}$ and $\mathrm{K}$. The "Agronomic Efficiency" and "Recovery Efficiency" of NPK of SSNM plot were higher than those of Farmer's practice as reported by Khuong et al., (2007).

\section{Available $\mathrm{N}, \mathrm{P}_{2} \mathrm{O}_{5}$ and $\mathrm{K}_{2} \mathrm{O}$ in soil}

The available nutrients in soil differed significantly with different nutrient 
management approaches at the end of cropping season. The balance of $\mathrm{N}$ and $\mathrm{P}$ were highest with farmer practice $(165.58,47.48$ and $263.31 \mathrm{~kg} \mathrm{~N}, \mathrm{P}$ and $\mathrm{K} \mathrm{ha}{ }^{-1}$, respectively) whereas treatment receiving SSNM approach $\left(133.59,47.48\right.$ and $253.12 \mathrm{~kg} \mathrm{~N}, \mathrm{P}$ and $\mathrm{K} \mathrm{ha}^{-1}$, respectively) resulted in higher balance of $\mathrm{K}$, $\mathrm{N}$ and $\mathrm{P}$ (Table 4). It could be due to enhanced nutrient pool at elevated fertility level which might have contributed to higher residual nutrient status of soil by retaining part of external applied nutrients in soil. Similar opinion of elevated fertility levels increased the available nutrient status of the soil after harvest of crop by several researchers. This might be due to release of nutrients from organic matter intern increases ' $\mathrm{N}$ ' in soil was more with SSNM treatments. It was also in accordance with Ramachandrappa et al., (2014) reported that the soil available nitrogen and potassium is low and phosphorus is medium in SSNM for a targeted finger millet yield of $4000 \mathrm{~kg} \mathrm{ha}^{-1}$ with the application of 155:45:203 kg N, $\mathrm{P}_{2} \mathrm{O}_{5}, \mathrm{~K}_{2} \mathrm{O}$ ha $^{-1}$.

\section{Economics of dry DSR as influenced by different nutrient management approaches}

Economics of any treatment is the deciding factor in many situation to judge its applicability in the field condition to recommend farming community to obtain better return with minimum investment in cultivation.

The cost of cultivation of dry DSR was higher $\left(₹ 48,714 \mathrm{ha}^{-1}\right)$ with farmers practice fertilization due to higher quantity of fertilizers application rates as compared to other treatments. SSNM approach registered cost of cultivation (₹42,867 ha $\mathrm{ha}^{-1}$ ) and these results are confirmation with findings of Wang et al., (2001) reported that the sitespecific nutrient management led to reduction of the average fertilizer cost by $\$ 15 \mathrm{ha}^{-1} \mathrm{crop}^{-1}$ and an increase in GRF by $\$ 88 \mathrm{ha}^{-1} \mathrm{crop}^{-1}$ compared with Farmer's practice.

Among the different treatments, the highest gross returns, net returns and $\mathrm{BC}$ ratio (₹1,58,431 $\mathrm{ha}^{-1}$, ₹ 1,15,564 $\mathrm{ha}^{-1}$ and 3.7, respectively) were recorded with SSNM approach followed by STCR approach (₹1,51,795 $\mathrm{ha}^{-1}$, ₹ 10,6,770 $\mathrm{ha}^{-1}$ and 3.4, respectively) and STL method(₹1,46,054 $\mathrm{ha}^{-1}$, $₹ 1,03,425 \mathrm{ha}^{-1}$ and 3.4 , respectively) as compared to farmer practice (₹1,39,949 $\mathrm{ha}^{-1}$, ₹91,235 $\mathrm{ha}^{-1}$ and 2.9, respectively) (Table 5) and rest of the other treatments. This is mainly due to higher grain and straw yield obtained with least investment in fertilizer brought lower cost of cultivation leads more gross returns, net returns and finally $\mathrm{BC}$ ratio.

These results corroborated the findings of Dhillon et al., (2006) noticed the superiority of the target yield concept over the other practices as it gave higher yields and optimal economic returns. Pampolinoa et al., (2007) evaluated the economic benefits of SSNM in farmer's fields. The results showed that the net annual benefit due to use of SSNM was US \$ $34 \mathrm{ha}^{-1}$ per year in Vietnam, 106 US \$ ha per year in the Philippines, and US \$ 168 $\mathrm{ha}^{-1}$ year in India. The increased benefit with SSNM was attributed to increased yield rather than reduced costs of inputs. Abdulrahman et al., (2002) the yields with SSNM were close to the yield goal and 16 per cent greater than the farmer's practice. The fertilizer cost was about US \$ $40 \mathrm{ha}^{-1}$ in both SSNM and FFP but the profitability (gross return over fertilizer cost) increased by US $\$ 130$ with SSNM due to increase in yield. Lowest gross returns, net returns and $\mathrm{BC}$ ratio ( $₹ 40,620$ ha ${ }^{1}$, ₹13,220 $\mathrm{ha}^{-1}$ and 1.5 , respectively) were obtained with absolute control. This is due to lower grain yield and without application of chemical fertilizer. The results are in close proximity with the findings of Wang et al., (2005) and Milapchand et al., (2006). 
Among the different nutrient management approaches, the SSNM approach produced significantly higher panicle length, maximum number of grains panicle ${ }^{-1}$, filled grains panicle $^{-1}$ and test weight, were recorded significantly higher $(24.16 \mathrm{~cm}, 296,280$ and $17.8 \mathrm{~g}$, respectively) with nutrients applied through SSNM approach as compared to absolute control, RDF and STL. However, it was on par with STCR and STL method. Total uptake (grain and straw) of nutrients was significantly higher with treatment receiving SSNM approach as compared to other treatments. However, it was on par with STCR approach and STL method. Further, omission of major nutrients has resulted in yield loss of 56 per cent $(-\mathrm{N}), 16.5$ per cent ($\mathrm{P})$ and 20 per cent (-K) compared to SSNM treatment. Application of fertilizers as per SSNM approach noticed higher nitrogen and phosphorus use efficiency. However higher potassium use efficiency of was noticed in STL rating method. Among the different treatments, the highest gross returns, net returns and $\mathrm{BC}$ ratio (₹ $1,58,431 \mathrm{ha-}^{1}$, ₹ $1,15,564 \mathrm{ha}^{-1}$ and 3.7 , respectively) were recorded with SSNM approach followed by STCR approach and STL method.

\section{References}

Abdulrahaman, S., Gines, H. C., Nagarajn, R., Satawathananont, S., Son, T. T., Tan, P. S. and Wang, G. H., 2002, Variation in the performance of site specific nutrient management among different environments with irrigated rice in Asia. Better Crops Int., 16(20): 18-23.

Biradar, D. P. and Aladakatti, Y. R., 2007, Site-Specific Nutrient Management (SSNM) - Another Green revolution in Northern Karnataka. Better Crops, 90(3).

Dhillon, N. S., Brar, B. S., Benipal, D. S. and Mavi, M. S., 2006, Economics of various soil test based fertilization approaches for different crops. Crop Res., 32(3): 377-381.

Doberman, A., Witt, C., Robert, P. C. and Larson, W. E., 2000, SSNM concept for irrigated via system. Proc. of 5th International Con. on Presis, 25: 1-7.

Jackson, M. L., 1973, Soil Chemical Analysis, Prentice Hall of India Pvt. Ltd., New Delhi, pp. 187.

Keram, K.S., Puri, G. and Sawarkar, S. D., 2012, Assessment of soil test based fertilizer recommendation under ricewheat cropping sequence and its impact on soil quality under agroclimatic condition of Kymore plateau zone of Madhya Pradesh, India. JNKVV Res. J., 46(1): 62-68.

Khuong Ttrinh Quang, Tran Thi Ngoc Huan, Phamsy Tan and Roland Buresh, 2007, Effect of site specific nutrient management on grain yield, nutrient use efficiency and rice production profit in the Mekong delta. Omonrice.15:153158.

Milapchand, Benbi, D. K. and Benipal, D. S., 2006, Fertilizer recommendations based on soil tests for yield targets of mustard and rapeseed and their validations under farmers field conditions in Punjab. $J$. Indian Soc. Soil Sci., 54(3): 316-321.

Mukopadhaya, D. and Majumdar, K., 2010, Response of rain fed rice to soil test based nutrient based application in terrai alluvial soils. Better Crops, 92: 13-15.

Ramachandrappa, B. K., Sathish, A., Dhanapal, G. N. and Srikanth Babu, P. N., 2014, Nutrient management strategies for enhancing productivity of dryland crops in Alfisols. Indian $J$. Dryland Agric. Res. \& Dev., 29(2): 4955.

Shaobing, P., Roland, J., Buresh., Jianliang, H., Xuhua, Z., Yingbin, Z., Jianchang, Y., 2006, Guanghuo,W., Yuanying, L., Ruifa, H., Qiyuan, T., Kehui, C., Fusuo, 
Z., Dobermann, A., Improving nitrogen fertilization in rice by site-specific $\mathrm{N}$ management. Agron. Sustain. Dev. 30:649-656.

Sharma, A. R. and Mittra, B. N., 1989, Effect of $\mathrm{N}$ and $\mathrm{P}$ on rice and their residual effect on succeeding wheat/gram crop. Indian J. Agron., 34(1): 40-43.

Singh, Y. V., Sharma, P. K. and Meena, R., 2014, Effect of soil test crop response technology on Productivity and economics of rice crop of Varanasi district of Uttar Pradesh. J. Rural \& Agric. Res., 14(1): 77-80.

Subbaiah, B. V. and Asija, G. L., 1956, A rapid procedure for the estimation of available nitrogen in soils. Cur. Sci., 25: 259-260.

Venkateshwarlu and Singh, M., 1980, Response of rice varieties to different spacings and fertility levels on yield attributes and yield. Indian J. Agron., 25(2): 263-272.

Wang, G., Zhang, Q. C., Witt, C., Buresh, R. J., 2007, Opportunities for yield increases and environmental benefits through site-specific nutrient management in rice systems of Zhejiang province, China. Agricultural Systems, 94: 801-806.

\section{How to cite this article:}

Rajesh, V., S.R. Balanagoudar, H. Veeresh, Ashok Kumar Gaddi and Ramesh, Y.M. 2018. Effect of Nutrient Management Approaches and Major Nutrients on Dry Direct Seeded Rice (dry- DSR) in TBP Command Area. Int.J.Curr.Microbiol.App.Sci. 7(02): 1239-1247. doi: https://doi.org/10.20546/ijcmas.2018.702.152 